\section{EREM 73/1}

Journal of Environmental Research, Engineering and Management Vol. 73 / No. 1 / 2017

pp. 20-32

DOI 10.5755/j01.erem.73.1.17988

(c) Kaunas University of Technology
Recent Extreme Floods and Their Transformation Along the Danube River

\title{
Recent Extreme Floods and Their Transformation Along the Danube River
}

\section{Maria Mikhailova}

Water Problems Institute, Russian Academy of Sciences Gubkina 3, Moscow, 119333 Russia

Corresponding author: mv.mikhailova@gmail.com

Maria Mikhailova, Water Problems Institute, Russian Academy of Sciences, Gubkina 3, Moscow, 119333 Russia

The article discusses the considerable changes in meteorological conditions and hydrological regime in the Danube River basin over the period from the late $20^{\text {th }}$ century to the early $21^{\text {st }}$ century. Particular attention is given to the recent extreme hydrological events in the Danube River basin: the disastrous rainfall flood that occurred in August 2002, and the extremely high spring-summer floods in 2006 and 2010. Specific features in the development and transformation of flood waves along the Danube River are discussed in detail, including the impact of the Iron Gate I Reservoir on these processes. In addition, the influence of the backwater effect of the Black Sea was evaluated, and probabilities of extreme floods were approximately estimated.

Keywords: Danube, rainfall, snowmelt, extreme flood, inundation.

\section{Introduction}

By the end of the $20^{\text {th }}$ century, the hydrological regime of the Danube River had been sufficiently well studied (Dunărea între Baziaş şi Ceatal Izmail, 1967, Hydrology of the Danube, 1988). The listed and other works generally characterised the Danube River hydrological regime over the period before 1970-1980. In these studies, strong floods and inundation such as floods in April 1942, May 1970, and June 1980 were mentioned. How- ever, regularities of the flood wave propagation along the Danube River were not studied. These earlier works could not consider the changes in the river regime due to climate change in Europe (IPCC, 2013), which happened at the end of the $20^{\text {th }}$ century and early $21^{\text {st }}$ century.

Climate change in the Danube River basin has resulted in strengthening of cyclonic activity, increase in air temperature, winter snow accumulation, annual rainfall, 
and ice regime softening. Strong extreme hydrological events, including snowmelt and rainfall floods, have become more frequent and intensive. Such extreme floods on the Danube River occurred in 2002, 2006, 2010, and 2013 (Flood Risk Management).

Some analysis of using information on flood wave propagation and transformation along the whole Danube River from Ingolstadt to the Black Sea was done (Flood Risk Management, Mikhailov et al., 2004, 2008, Mikhailova et al., 2012). These long-term studies were carried out with participation of the author in a frame of cooperation between the Faculty of Geography of Moscow State University, Water Problems Institute of Russian Academy of Sciences, and the Danube Hydrometeorological Observatory in the town of Izmail (Ukraine). These results have made it possible to reveal considerable recent changes in the climatic and hydrological characteristics in the Danube River basin. This new article is the result of the continuing research based on previous works but has a wider approach. The main objectives of this new article are the following: (i) to use complete observation data of the extreme floods in 2002, 2006 and 2010 for the detailed research of the formation and development of these floods in the Danube River basin, and propagation and transformation of flood waves along the river from its upper stretches to the Black Sea; (ii) to reveal similarities and differences of these events; (iii) to assess influence of natural and anthropogenic factors, including meteorological conditions, impacts of large tributaries, the Iron Gate I Reservoir, backwater and stabilising effect of the sea water level on these floods; and (iv) to estimate the probability of extreme floods.

\section{Materials and methods}

The data on the network of gauging stations along the Danube River (Figure 1) are used in this article; the gauging stations are known for their unique series of observations lasting up to 120-150 years.

Fig. 1

Map of the Danube River basin and position of gauging stations

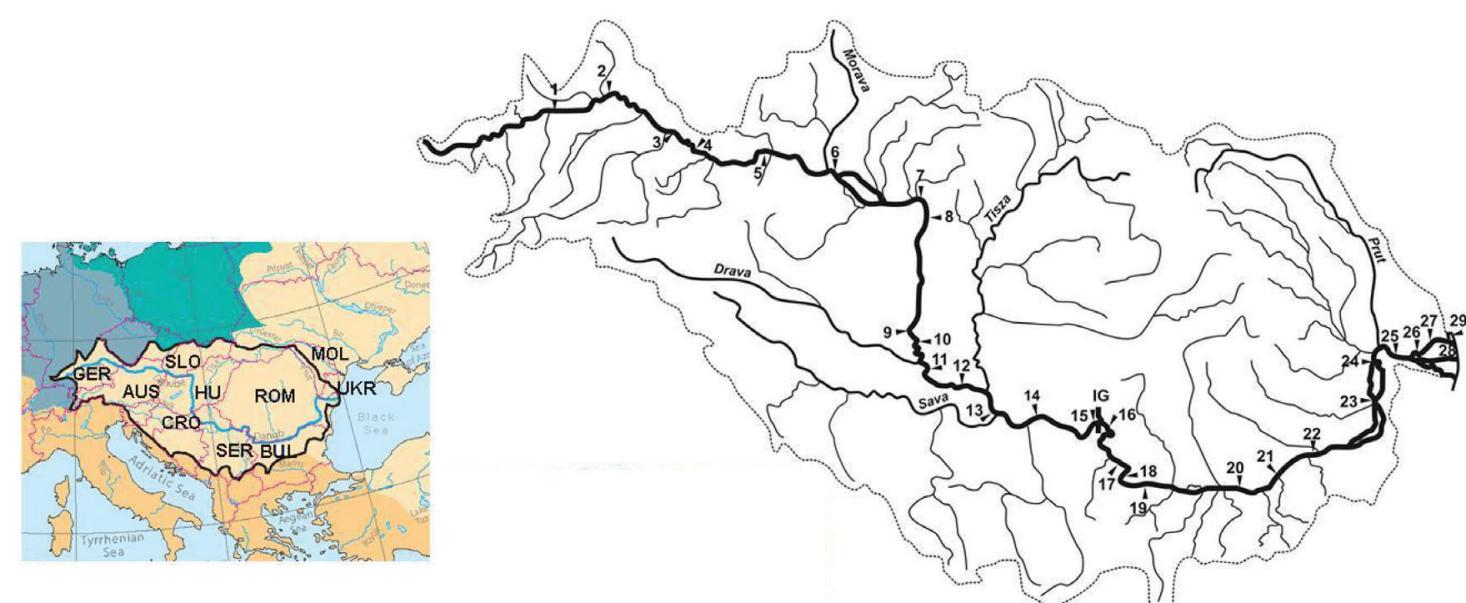

1 - Ingolstadt (Germany);

2 - Regensburg (Germany);

3 - Passau (Germany);

4 - Linz (Austria);

5 - Kienstock (Austria);

6 - Bratislava (Slovakia);

7 -Nagymaros (Hungary);

8 - Budapest (Hungary);
9 - Mohacs (Hungary);

10 - Bezdan (Croatia):

11 - Bogojevo (Croatia);

12 - Novi Sad (Serbia);

13 - Zemun (Serbia);

14 - Bazias (Romania);

15 - Orsova (Romania);

16 - Turnu Severin (Romania);
17 - Novo Selo (Bulgaria);

18 - Calafat (Romania);

19 - Lom (Bulgaria);

20 - Zimnicea (Romania);

21 - Giurgiu (Romania);

22 - Oltenita (Romania):

23 - Hirsova (Romania);

24 - Braila (Romania);
25 - Reni (Ukraine);

26 - Izmail (Ukraine);

27 - Kiliya (Ukraine);

28 - Vilkovo (Ukraine);

29 - Primorskoye (Black Sea)

(Ukraine).

IG is the dam of the Iron Gate I

Reservoir 
Analysis of water level variations during floods was made for 3 parts of the Danube River: upper, middle and lower Danube. The upper Danube starts at the river's source in the Black Forest in Germany and flows to the Gate of Devin near Bratislava. The middle Danube is a stretch from the Gate of Devin to the Iron Gate (the gorge forming the boundary between Serbia and Romania). The lower Danube starts at the Iron Gate Gorge, and flows to the Black Sea; this reach includes the Danube delta.

The largest hydropower dam and reservoir system along the entire Danube is located at the 117-km long Iron Gate Gorge (Djerdap). This system consists of two dams and the reservoirs of Iron Gate I and Iron Gate II, located 943 and $863 \mathrm{~km}$ from the Black Sea, respectively. The Iron Gate I Reservoir (upstream of Drobeta-Turnu Severin town) has existed since 1971. This reservoir with the effective storage of $3.2 \mathrm{~km}^{3}$ has a noticeable impact on the river flood regime. The Iron Gate II Reservoir (downstream of Drobeta-Turnu Severin) was filled in 1984.

Table 1 includes a list of gauging stations from Ingolstadt (the upper Danube) to Primorskoye (the coast of the Black Sea near the Danube delta). The observation data from all gauging stations on the Danube River are available in the Archives of the Danube Hydrometeorological Observatory, and they include information obtained as a result of data exchange with other Danube countries located along the Danube River within the framework of international cooperation in the field of Danube hydrometeorology.

Tables 1-3 with the highest water levels were presented to analyse the development and formation of flood waves during the extreme hydrological events in 2002 , 2006 and 2010. River floods can be considered as extreme events, if water levels during hydrological events exceed their historical values in the previous period at least at several gauging stations. The comparison of the highest water levels during these extreme floods with the historical maxima over the entire observation period was given in these tables. The values of historical maxima were accounted only for periods without ice phenomena. The graphs of the Danube River water level variation during extreme floods were constructed. The heights of the flood waves were calculated as a difference between the water level at the wave peak and the low water level in the previous period.

\section{Results and discussion}

\section{Hydrometeorological precondition for recent extreme floods in the Danube River basin}

From the end of the $20^{\text {th }}$ century, the cyclonic activity has increased in Europe and, in particular, over the Danube River basin. Heavy rains became more frequent; waves and storm surges at the seacoasts became more intense as well.

The latest decades show more frequent extreme hydrological events in the Danube River basin. These events were manifested in severe rainfall floods, spring-summer floods, and severe drought in 2003. Such extreme hydrological events were exemplified during the most disastrous rainfall flood in August 2002, and the extreme spring-summer floods in 2006 and 2010. The features of these events show the processes of not only regional but also global nature (IPCC, 2013).

The extreme flooding events in 2002, 2006 and 2010 took place against a backdrop of increased water discharges into the Danube River basin, induced by climate change over the second half of the $20^{\text {th }}$ century. The $54-$ mile hydrometric cross-section - upstream from the Danube delta head - has served to collect long-term observation data of the Danube River discharges. This data, when compared with the water levels at the Reni gauging station revealed the following: the Danube River water discharges gradually increased in the last 175 years. This indicates that, first, the difference between precipitation and evaporation in the Danube River basin steadily increased and, second, the influence of climatic factors on the river water regime of the Danube River was greater than the impact of the human factor (water abstraction for economic use).

The results of our studies concluded the following:

the long-term average annual water discharge of the Danube River at the delta head over the whole observation period from 1840 to 2002 (163 years) was $6,320 \mathrm{~m}^{3} / \mathrm{s}\left(199 \mathrm{~km}^{3} /\right.$ year);

the Danube River water discharges started to grow from the 1970s, and this trend now continues;

the long-term average annual water discharge over the period of $2003-2015$ was $6,740 \mathrm{~m}^{3} / \mathrm{s}$; 
the largest average annual water discharges over this period were in $2010\left(9,470 \mathrm{~m}^{3} / \mathrm{s}\right), 2005\left(8,530 \mathrm{~m}^{3} / \mathrm{s}\right)$, and $2006\left(8,240 \mathrm{~m}^{3} / \mathrm{s}\right)$;

in the most high-flow years, the share of flood flow in the annual water flow amounted to $60.8 \%$ (in 2006) and $50.4 \%$ in (2010). In low-flow years, the share of flood flow was only $44.8 \%$ (in 2003) and $41.9 \%$ (in 2007) of the annual water flow;

in recent decades, the spring-summer flood peak begins 10-15 days (on the average) earlier than in previous years; this is related to earlier snowmelt in the Danube River basin caused by the general climate change and global warming.

Because of the increase in Danube River water discharges, the water balance of the Black Sea has changed. The increase of seawater storage has resulted in the acceleration of the sea level rise. The analysis of water level observations at the gauging station of Primorskoye (nearshore zone of the Danube River mouth) revealed that, during 1985-2010, the rate of the sea water level rise was $6.9 \mathrm{~mm} /$ year. This value exceeds the data available for the entire World Ocean by 1.5-2 times in the same period.

\section{Extreme summer rainfall flood in 2002}

In the first half of August 2002, a sharp frontal atmospheric zone was formed in Western Europe. This frontal zone was characterised by the interaction of the Atlantic humid tropical air ranging from $28^{\circ} \mathrm{C}$ to $35^{\circ} \mathrm{C}$, and the Arctic air, which rarely exceeds $18-23^{\circ} \mathrm{C}$. Heavy rains covered the southern and eastern parts of Germany, Austria, the Czech Republic, and Slovakia, as well as adjacent territories. Heavy rainfall in the upper Danube River basin as well as in the upper stretches of the Elbe River was recorded August 6-7, followed by another episode shortly after, August 11 through 12. The first wave of heavy rains caused river floods in Germany (in the lands of Saxony and Bavaria) and throughout the Western and Southern parts of the Czech Republic (Mikhailov et al., 2004). The formation of the first rainfall flood wave began on the upper Danube River (in the stretch from the source of the river to the inflow of the Morava River) on August 6. The first flood peak was recorded on August 8-9 at the gauging stations of Ingolstadt, Regensburg, Passau, Linz, Kienstock (80 km upstream of Vienna), and Bratislava. The highest water levels at gauging stations along the Danube River during this flood and over the entire observation period are presented in Table 1. The peak of the second flood wave in the stretch between Ingolstadt and Kienstock was virtually observed simultaneously, i.e., on August 13-16. Only in the stretches downstream of Kienstock, the flood looked as a well-defined flood wave moving downstream. The maximum water level in Bratislava (at the beginning of the middle Danube River) was recorded on August 16. The sudden water level rise in the Danube River near Bratislava can also be explained by the fact that, somewhat upstream of Devin, the Danube River receives the large left tributary of Morava, in which the rainfall flood also was formed. Moving at a rate of $73 \mathrm{~km} /$ day, the flood wave peak covered the $146-\mathrm{km}$ distance between Kienstock and Bratislava in two days.

The water level in Budapest began rising around August 8 . The second flood wave covered the distance from Bratislava to Budapest $(222 \mathrm{~km})$ in 3 days at a rate of 74 $\mathrm{km} /$ day. The flood peak was recorded in Budapest on August 19. By August 22, the flood wave reached Mohacs (at the border between Hungary and Croatia). The flood wave covered the distance from Budapest to Mohacs $(200 \mathrm{~km})$ in 3 days at a rate of $67 \mathrm{~km} /$ day. The maximum water levels within the territory of Croatia were recorded at the gauging stations of Bezdan on August 22 and at the gauging station of Bogojevo on August 23. Moving at a rate of $64 \mathrm{~km} /$ day, the flood wave covered the distance from the gauging station of Mohacs in Hungary to the gauging station of Novi Sad in Serbia (192 $\mathrm{km}$ ) in 3 days, and the distance from Novi Sad gauging station to Zemun gauging station $(82 \mathrm{~km})$ was covered in 2 days at a rate of $41 \mathrm{~km} /$ day. The maximum water levels were recorded here on August 25 and 27.

On August 28, the flood peak was observed at Bazias gauging station. Thus, the flood wave in the middle Danube stretches (from Bratislava to the Iron Gate I Reservoir) propagated for about 12 days. The flood wave flattened in this stretch, and its height decreased from 6.0 to $0.5 \mathrm{~m}$ (Table 1 ).

Before the construction of the reservoir in 1971, the $120-\mathrm{km}$ Danube stretch $(950-1,070 \mathrm{~km}$ from the Black Sea), full of rapids and called cataracts or Iron Gate, was characterised by sudden wedging of flood waves 


\section{Table 1}

The highest water levels at gauging stations along the Danube River during summer flood in 2002. Here and in Tables 2-3, the asterisk indicates that water level exceeded the historical maximum. The dash means lack of information

\begin{tabular}{|c|c|c|c|c|c|c|c|}
\hline \multirow[b]{2}{*}{ Number } & \multirow{2}{*}{$\begin{array}{l}\text { Name of gauging } \\
\text { station }\end{array}$} & \multicolumn{3}{|c|}{ Flood in 2002} & \multicolumn{3}{|c|}{ Values of historical maxima before 2002} \\
\hline & & $\begin{array}{l}\text { Level above } \\
\qquad 0 », \mathrm{~cm}\end{array}$ & Data & $\begin{array}{c}\text { Height of } \\
\text { flood wave, m }\end{array}$ & $\begin{array}{l}\text { Observation } \\
\text { period }\end{array}$ & Level, cm & Data \\
\hline 1 & 2 & 3 & 4 & 5 & 6 & 7 & 8 \\
\hline 1 & Ingolstadt & 642 & 14.08 & 3.9 & $1827-2001$ & 778 & 18.06.1910 \\
\hline 2 & Regensburg & 627 & 15.08 & 2.8 & $1884-2001$ & 666 & 28.03.1988 \\
\hline 3 & Passau & 1083 & 13.08 & 5.5 & 1877-2001 & 1,230 & 10.07.1954 \\
\hline 4 & $\operatorname{Linz}$ & 799 & 13.08 & 4.2 & $1893-2001$ & 963 & 11.07.1954 \\
\hline 5 & Kienstock & $1085^{*}$ & 14.08 & 7.8 & $1830-2001$ & 896 & 13.07.1954 \\
\hline 6 & Bratislava & $986^{*}$ & 16.08 & 6.5 & 1823-2001 & 984 & 15.07.1954 \\
\hline 7 & Nagymaros & $707^{*}$ & 18.08 & 6.0 & 1876-2001 & 682 & 17.06 .1965 \\
\hline 8 & Budapest & 844 & 19.08 & 6.3 & $1876-2001$ & 845 & 17.06 .1965 \\
\hline 9 & Mohacs & 924 & 22.08 & 6.5 & 1876-2001 & 984 & 19.06.1965 \\
\hline 10 & Bezdan & 712 & 22.08 & 6.0 & 1876-2001 & 776 & 24.06 .1965 \\
\hline 11 & Bogojevo & 727 & 23.08 & 6.0 & 1890-2001 & 817 & 15.06 .1965 \\
\hline 12 & Novi Sad & 602 & 25.08 & 4.6 & 1888-2001 & 778 & 30.06 .1965 \\
\hline 13 & Zemun & 470 & 27.08 & 2.0 & 1876-2001 & 757 & 26.03.1981 \\
\hline 14 & Bazias & 628 & 28.08 & 0.50 & 1874-2001 & 795 & 06.04 .1942 \\
\hline 15 & Orsova & 2540 & 01.08 & - & 1888-2001 & 2,568 & 17.10 .1994 \\
\hline 16 & Turnu Severin & 831 & 27.08 & 1.5 & 1879-2001 & 906 & 28.03.1981 \\
\hline 17 & Novo Selo & 513 & 28.08 & 3.6 & $1941-2001$ & 900 & 28.03.1981 \\
\hline 18 & Calafat & 415 & $22,28.08$ & 3.0 & 1879-2001 & 801 & 29.03.1981 \\
\hline 19 & Lom & 558 & $28-29.08$ & 3.6 & 1921-2001 & 934 & 29.03.1981 \\
\hline 20 & Zimnicea & 411 & 30.08 & 3.1 & 1879-2001 & 800 & 02.06 .1970 \\
\hline 21 & Giurgiu & 376 & $24,30.08$ & 3.2 & 1879-2001 & 795 & 02.03.1970 \\
\hline 22 & Oltenita & 393 & 31.08 & 3.2 & 1879-2001 & 784 & 1897 \\
\hline 23 & Hirsova & 413 & 02-03.09 & 3.2 & 1898-2001 & 727 & $04-06.06 .1970$ \\
\hline 24 & Braila & 431 & 02-03.09 & 2.7 & 1874-2001 & 639 & 28.05.1970 \\
\hline 25 & Reni & 350 & 02.09 & 2.6 & $1921-2001$ & 555 & 28.05.1970 \\
\hline 26 & Izmail & 238 & 01.09 & 1.7 & $1921-2001$ & 420 & 22.05.1970 \\
\hline 27 & Kiliya & 142 & 31.08 & 0.92 & $1921-2001$ & 282 & 02.04 .1942 \\
\hline 28 & Vilkovo & 128 & 31.08 & 0.59 & $1921-2001$ & 191 & 19.02.1979 \\
\hline 29 & Primorskoye & 519 & 12.09 & 0.45 & 1951-2001 & 599 & 19.02.1979 \\
\hline
\end{tabular}


(Hydrology of the Danube, 1988, Dunărea între Baziaş şi Ceatal Izmail, 1967). This was due to the hydraulic features of water stream movement in a channel reach having very steep water surface slopes (up to $4 \%$ in very low-flow periods) and considerable flow velocities. Before the reservoir construction, the cataracts located at distances of $945-950 \mathrm{~km}$ and $990-1,100 \mathrm{~km}$ from the Black Sea acted as large spillways, where seasonal water level fluctuations did not exceed 2-3 $\mathrm{m}$ in rapid areas. The drop in flood wave height (as in 1954) began somewhere upstream of the cataracts in the reach downstream of Bogojevo gauging station (Figure 2).

When the Iron Gate I Reservoir was filled by 1971, the hydraulic conditions upstream the dam substantially changed. The water head at the dam was $32 \mathrm{~m}$ under the condition of the normal backwater level; during rainfall flood and spring-summer floods, the reservoir effective storage was drown down and the water head at the dam was reduced by $6.5 \mathrm{~m}$, i.e., to the level of the dead storage.
As seen from Figure 2, flattening of the rainfall flood waves as in 2002 (and spring-summer flood waves, see below) began further upstream than before 1971, i.e., at Mohacs. It was caused by the backwater propagated upstream at a distance of $270 \mathrm{~km}$, and the drawdown of the reservoir effective storage. The height of rainfall and spring-summer flood waves decreases to $2.4-0.5 \mathrm{~m}$ in the zone of variable backwater (Zemun and Bazias) and within the reservoir (Orsova) it acquires negative values. The cited data on the flood wave velocity along the Danube point to its gradual slowing down within the reach of Budapest - Iron Gate I Reservoir (from 74 to $41 \mathrm{~km} /$ day). This slowing down is also typical of the spring-summer flood waves, which is due to the backwater effect of reservoirs.

Water levels in the lower Danube stretches started to rise on August 9, when the release of water from the reservoirs of Iron Gate I and II began. The release of water was completed beforehand with a prospective to receive the floodwater and to attenuate, if possible, the flood in the river stretch downstream of the reservoirs.

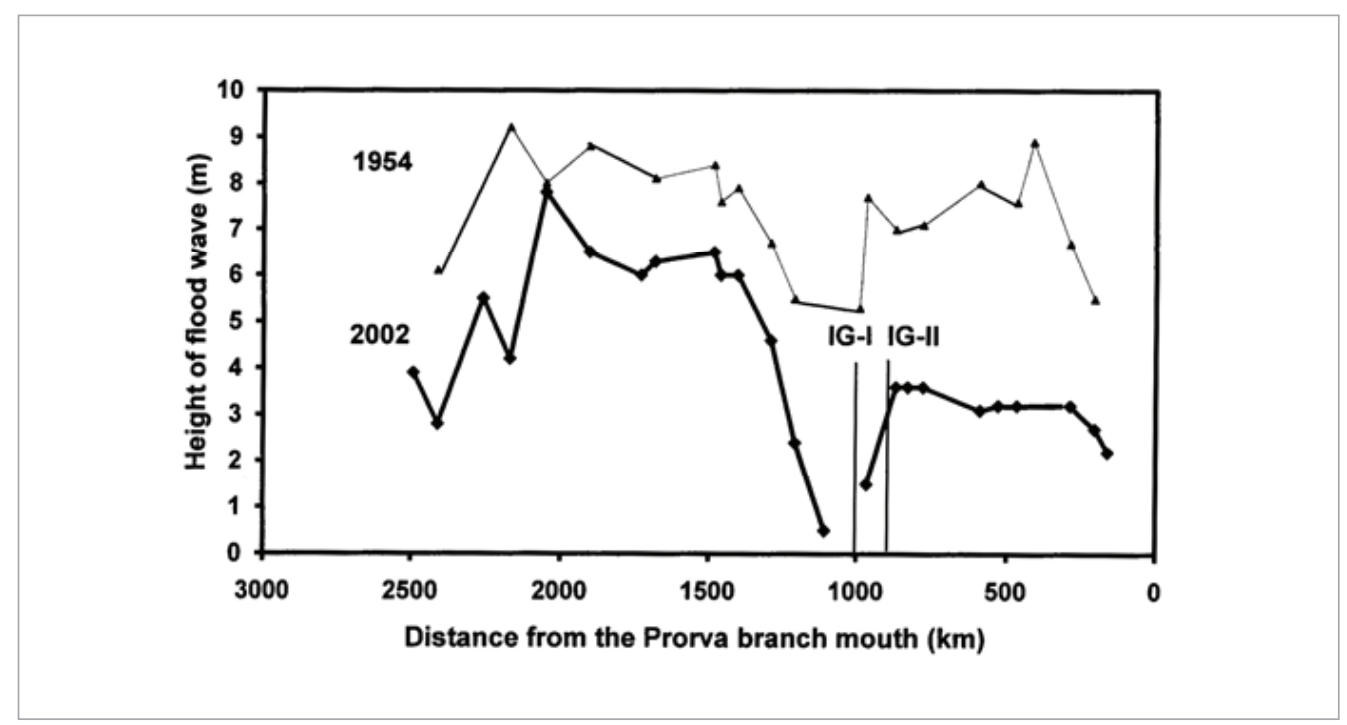

Fig. 2

Changes of height of flood waves along the Danube River in August 2002 and July 1954. IG-I and IG-II dams of the Iron Gate I and Iron Gate II reservoirs
From August 9 to 16, the water level in the upper pond of the reservoir was lowered by $90 \mathrm{~cm}$ and, from August 17 to 22 , the reservoir water level was decreased by 170 $\mathrm{cm}$ more. By the time when the flood wave reached the Iron Gate (August 26-27), the reservoir drawdown was $260 \mathrm{~cm}$. This enabled the accumulation of the main flood volume in the reservoir and prevention of further water level rising in the lower Danube stretches. The flood wave in the lower Danube stretches (from Turnu Severin to the sea) was a result of the water release from the Iron Gate I Reservoir rather than a rainfall flood.

As for the Romanian stretch of the Danube River, the water level started to rise at Calafat on August 9 (when water release from the reservoir began). By August 22, 
the water level reached its maximum. Similar variations in the water level occurred at Zimnicea, Giurgiu, and Oltenita (Table 1). The water level rise at the first 2 stations began on August 9 and reached its maximum on August 30. The highest water level at Oltenita was recorded on August 31. The water level rise at Hirsova and Braila (Romania) and at Reni (Ukraine) began on August 10-11, and the maximum values were reached on September 2. The release wave from Calafat to Reni $(668 \mathrm{~km})$ propagated at a rate of $61 \mathrm{~km} /$ day over the period of 11 days.

The release wave rapidly flattened along the lower Danube stretches (Table 1, Figure 2). Such flattening is a typical process in the lowermost part of the large river, flowing into the sea. This is connected with the stabilising influence of the sea water level (the eustatic sea level rise is very small in comparison with the flood wave height) and a widening of the river channel and floodplain towards the sea (Гидрология дельты Дуная, 2004).

The second and more intense flood wave, which was observed in the second half of August 2002, resulted in a catastrophic river water level rise through $600-\mathrm{km}$ stretch between Passau and Budapest. Water levels at the gauging stations of Kienstock, Bratislava, and Nagymaros exceeded the historical maxima, while the water level at Budapest was only $1 \mathrm{~cm}$ below its historical maximum (Table 1). The rainfall flood caused a severe inundation to the point that some districts of the town of Regensburg were submerged. Many residential areas between Vienna and the Austrian-Hungarian border were also submerged. Vienna, however, did not sustain significant damages due to defence dikes, which confined the water head.

After the disastrous flood in August 2002, a multipurpose programme for flood control in the Danube River basin was put in place. In November 2002, the International Commission for the Protection of the Danube River (ICPDR) decided to establish the long-term Action Programme for Sustainable Flood Prevention in the Danube River basin. The goal of the Action Programme was to achieve a long-term and sustainable approach in managing the risks of floods, and to protect human life and property, while encouraging conservation and improvement of water related ecosystems (Flood Action Programme, 2004).

\section{Extreme spring-summer flood in 2006}

The extreme spring-summer flood in 2006 was generally (in terms and duration) similar to spring-summer floods in other high-flow years; however, it was more intense. In December 2005, the intense cyclonic activity in the Danube River basin caused considerable precipitation, which exceeded the normal value by $20 \%$ (Mikhailov et al., 2012). This predetermined the accumulation of large quantities of snow. The following spring of the year 2006 was moderately warm and humid in the Danube River basin. The amount of precipitation over the spring months substantially exceeded the monthly normal values by 55\% in March, 35\% in April, and $6 \%$ in May (Mikhailov et al., 2012). In early summer, the weather in the upper and middle Danube areas was characterised by cyclonic activity and heavy rains.

The total precipitation at many meteorological stations (for example, in the basins of the upper Danube, Morava, Tisza, and Sava rivers) turned out to be above the normal value, particularly, in December 2005 and March through May 2006 (Mikhailov et al., 2012). Thus, the main causes of the large spring-summer flood between March and June 2006, were: first, considerable snow accumulations in mountain areas and in the plain by the beginning of March; second, warm weather in spring (March-April), which favoured intense snow melting; and third, heavy rains in spring-summer months.

In 2006, short-duration rainfall floods were clearly defined at the gauging stations from Ingolstadt to Kienstock (upper Danube River). These floods occurred in the first half of March, at the beginning of May, and in late May - early June. The longer water level rise as a result of snowmelt and rains was present in late March and the first half of April. The joint impact of snowmelt and rainfall feeding resulted in the formation of two spring-summer flood waves in March-April and in late May - early June. The highest water levels at the gauging stations of the upper Danube stretches were observed between the end of March and early April (Table 2, Figure 3), i.e., during the first spring-summer flood wave. The height of this wave increased from 3-3.3 m (Ingolstadt and Regensburg) to 4.5-5.5 m (Passau and Kienstock).

Two spring-summer flood waves were also clearly defined at the gauging stations of the middle Danube stretches from Bratislava to Bazias inclusive; they were 


\section{Table 2}

The highest water levels at gauging stations along the Danube River during spring-summer flood in 2006. Here and in Table 3, the dash means that the flood wave height cannot be estimated exactly

\begin{tabular}{|c|c|c|c|c|c|c|c|}
\hline \multirow[b]{2}{*}{ Number } & \multirow{2}{*}{$\begin{array}{l}\text { Name of gauging } \\
\text { station }\end{array}$} & \multicolumn{3}{|c|}{ Food in 2006} & \multicolumn{3}{|c|}{ Values of historical maxima before 2006} \\
\hline & & $\begin{array}{l}\text { Level above } \\
\text { «0», cm }\end{array}$ & Data & $\begin{array}{c}\text { Height of } \\
\text { flood wave, } m\end{array}$ & $\begin{array}{l}\text { Observation } \\
\text { period }\end{array}$ & Level, cm & Data \\
\hline 1 & 2 & 3 & 4 & 5 & 6 & 7 & 8 \\
\hline 1 & Ingolstadt & 476 & 11.03 & - & 1827-2005 & 778 & 18.06.1910 \\
\hline 2 & Regensburg & 523 & 30.03 & 3.3 & 1884-2005 & 666 & 28.03.1988 \\
\hline 3 & Passau & 863 & 29.03 & - & 1877-2005 & 1,230 & 10.07.1954 \\
\hline 4 & $\operatorname{Linz}$ & 613 & 29.03 & - & 1893-2005 & 963 & 11.07.1954 \\
\hline 5 & Kienstock & 789 & 30.03 & - & 1830-2005 & 1,085 & 14.08.2002 \\
\hline 6 & Bratislava & 829 & 02.04 & 5.9 & 1823-2005 & 986 & 16.08.2002 \\
\hline 7 & Nagymaros & $713^{*}$ & 04.04 & - & 1876-2005 & 707 & 18.08.2002 \\
\hline 8 & Budapest & $856^{*}$ & 04.04 & 7.6 & 1876-2005 & 845 & 17.06.1965 \\
\hline 9 & Mohacs & 931 & 08-09.04 & - & 1876-2005 & 984 & 19.06.1965 \\
\hline 10 & Bezdan & 734 & 10.04 & - & 1876-2005 & 776 & 24.06 .1965 \\
\hline 11 & Bogojevo & 791 & 10.04 & - & 1890-2005 & 817 & 15.06.1965 \\
\hline 12 & Novi Sad & 745 & 12.04 & 5.7 & 1888-2005 & 778 & 30.06 .1965 \\
\hline 13 & Zemun & $783^{*}$ & 17.04 & 2.6 & 1876-2005 & 757 & 26.03.1981 \\
\hline 14 & Bazias & $807^{*}$ & $15-17.04$ & - & 1874-2005 & 795 & 06.04 .1942 \\
\hline 15 & Orsova & 2450 & 01.06 & - & 1971-2005 & 2,568 & 17.10.1994 \\
\hline 16 & Turnu Severin & $928^{*}$ & 2704 & 2.8 & 1879-2005 & 906 & 28.03.1981 \\
\hline 17 & Novo Selo & $922^{*}$ & 2004 & - & 1941-2005 & 900 & 28.03.1981 \\
\hline 18 & Calafat & $861^{*}$ & $22-23.04$ & 8.0 & 1879-2005 & 801 & 29.03.1981 \\
\hline 19 & Lom & $985^{*}$ & 23.04 & - & 1921-2005 & 934 & 29.03.1981 \\
\hline 20 & Zimnicea & $839^{*}$ & 24.04 & - & 1879-2005 & 800 & 02.06 .1970 \\
\hline 21 & Giurgiu & $822^{*}$ & 24.04 & 7.6 & 1879-2005 & 795 & 02.06 .1970 \\
\hline 22 & Oltenita & 809 & 24.04 & - & 1879-2005 & 784 & 1897 \\
\hline 23 & Hirsova & $764^{*}$ & 25.04 & - & 1898-2005 & 727 & $04-06.06 .1970$ \\
\hline 24 & Braila & $699^{*}$ & 26.04 & - & 1874-2005 & 639 & 28.05 .1970 \\
\hline 25 & Reni & $562^{*}$ & 26.04 & 4.0 & $1921-2005$ & 555 & 28.05 .1970 \\
\hline 26 & Izmail & 400 & 25.04 & 2.7 & 1921-2005 & 420 & 22.05 .1970 \\
\hline 27 & Kiliya & 249 & 02.05 & 1.7 & 1921-2005 & 282 & 02.04 .1942 \\
\hline 28 & Vilkovo & 189 & 01.05 & 1.1 & 1921-2005 & 191 & 19.02.1979 \\
\hline 29 & Primorskoye & 538 & 01.05 & 0.5 & 1951-2005 & 599 & 19.02.1979 \\
\hline
\end{tabular}


observed from mid-March to early May and in the first half of June (Figure 3). Rainfall floods gradually merged with 2 spring-summer flood waves and, by the end of the stretch, the flood waves were slightly flattened.

Extreme water levels were observed in the middle Danube stretches later than in the upper Danube River; they were recorded from the beginning to mid-April, i.e., also during the first spring-summer flood wave. The most significant water level rise, which exceeded the historical maximum, was recorded in the upper part of the middle Danube stretches at Nagymaros and Budapest. The level rise here was caused by the additional water inflow from the Morava River, a large left tributary. The historical maxima were also exceeded at Zemun and Bazias, downstream of the confluence of the Danube River with the water-abundant tributaries of Tisza and Sava (Table 2, Figure 3).

The height of the flood waves rapidly increased along the middle Danube stretches from $5.5 \mathrm{~m}$ (Bratislava) to 6.5-7.0 m (Nagymaros and Budapest), then dropping

Fig. 3
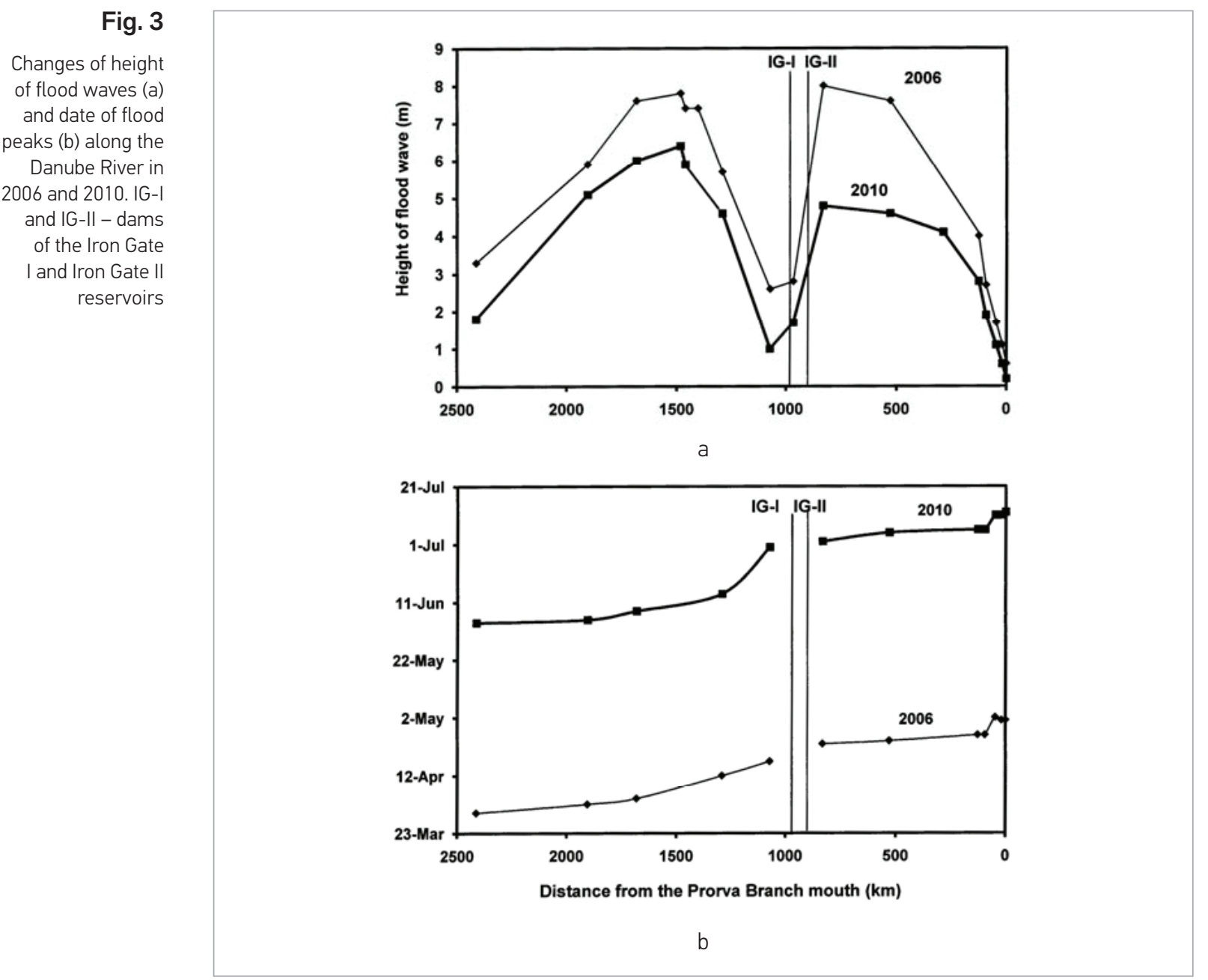

to $6.0 \mathrm{~m}$ downstream of this area. The water level rise approximated $2.5 \mathrm{~m}$ at Bazias located in the zone of the backwater impact of the Iron Gate I Reservoir (Figure 5). During the spring-summer flood, the release of wa- ter led to a 6-meter drop of the reservoir water levelnearly to the level of the dead storage (Table 2).

The spring-summer flood in 2006 took on the most extreme features in the lower Danube stretches (par- 
ticularly, between Calafat and Braila). In 2006, the level regime on the lower Danube River was modified by the water discharges from the reservoirs.

Extreme water levels in the stretch from Turnu Severin to Reni were observed during the first spring-summer flood wave at the end of April, when they exceeded their historical maxima throughout the length of this stretch (Table 2). The spring-summer flood height rapidly increased up to $7.0-7.5 \mathrm{~m}$ in the downstream direction (the gauging stations of Novo Selo, Calafat, Lom, Zimnicea, Giurgiu, and Oltenita). Thereafter, the process of spring-summer flood wave flattening began: the wave height decreased to about $6 \mathrm{~m}$ (Hirsova), $5 \mathrm{~m}$ (Braila), and $4 \mathrm{~m}$ (Reni) (Table 2, Figure 3). The value of the water level rise during the spring-summer flood in 2006 gradually decreased in the direction to the Black Sea: from $4.0 \mathrm{~m}$ (Reni) to $2.7 \mathrm{~m}$ (Izmail), $1.7 \mathrm{~m}$ (Kiliya), and $1.0 \mathrm{~m}$ (Vilkovo) (Table 3, Figure 3).

The spring-summer flood in 2006 differs from other similar floods in the following ways: greater than usual snow accumulation, earlier snowmelt and its intense development, heavy rains, and simultaneous formation of spring-summer flood within the entire basin area with participation of large tributaries.

On April 20 and 21, 2006, the Danube Hydrometeorological Observatory measured at the 54-mile hydrometric cross-section (somewhat upstream of the delta head) water discharges 15,800 and $15,900 \mathrm{~m}^{3} / \mathrm{s}$ at the water levels at Reni of 553 and $555 \mathrm{~cm}$, respectively. In accordance with the stage-discharge curve, the highest water discharge of the Danube River during the springsummer flood peak on April 26 (at the level of $562 \mathrm{~cm}$ at Reni) was bound to be about $16,000 \mathrm{~m}^{3} / \mathrm{s}$. According to the probability curve of maximum water discharges for the period of 1971-2002 (Гидрология дельты Дуная, 2004), the probability of this discharge should have been close to $1 \%$.

The spring-summer flood in 2006 resulted in strong inundation in the lower Danube stretches. As for Romania alone, about 90,000 ha of agricultural lands and 1,000 $\mathrm{km}$ of roads were submerged here; the emergency zone included 147 settlements of which 227 houses were ruined and 800 houses were damaged; 12,000 dwellers were evacuated.

\section{Extreme spring-summer flood in 2010}

In early February 2010, snow storage in the Danube River basin was considered significant (Mikhailova et al., 2012). In the second decade of February, warm and rainy weather set in along the Danube River; this resulted in intense snowmelt and the formation of the first wave of the spring-summer flood. By mid-March, snow storage was again replenished in the Danube River basin. The second wave of the spring-summer flood formed much later - at the beginning of the third decade of May due to heavy rains.

Two phases of the spring-summer flood were formed in the river basin in March and June-July. The highest water levels were recorded at gauging stations in the upper Danube stretches in the first half of March, i.e., during the first wave of the spring-summer flood (Table 3, Figures 3). Two waves of the flood were also well manifested at gauging stations of the middle Danube stretches from Bratislava to Bazias inclusive; the first wave was observed from March 3 to March 9, and the second higher wave was observed from June 5 to June 14 (Table 3, Figure 3).

The specific features of the spring-summer flood in 2010 are best shown throughout the entire length of the lower Danube River (Table 3, Figure 3) (particularly between Calafat and Kiliya). In 2010, the water level regime in the lower Danube stretches was transformed by the water discharge from the Iron Gate I Reservoir (Table 3, Figures 3).

The Siret and Prut River floods, caused by heavy rains, were superimposed on the spring-summer flood wave on the lower Danube River. The second wave of the spring-summer flood in the lower Danube stretches was observed in the first decade of July. The maximum water level was observed at Calafat on July 2 (its rise was equal to $4.8 \mathrm{~m}$ ); the maximum water level was recorded at Giurgiu on July 5. The water level of 713 $\mathrm{cm}$, which exceeded the historical maximum in 2006 by $14 \mathrm{~cm}$, was recorded at Braila on July 6 . The historical maxima were also exceeded in the Romanian part of the lower Danube River at Galati, Isaccea, and Tulcea. The historical maximum was exceeded in the Ukrainian part of the river at Reni $(581 \mathrm{~cm})$ on July 5-6 (Table 3). 


\section{Table 3}

The highest water levels at gauging stations along the Danube River during spring-summer flood in 2010

\begin{tabular}{|c|c|c|c|c|c|c|c|}
\hline \multirow[b]{2}{*}{ Number } & \multirow{2}{*}{$\begin{array}{c}\text { Name of } \\
\text { gauging station }\end{array}$} & \multicolumn{3}{|c|}{ Flood in 2010} & \multicolumn{3}{|c|}{ Values of historical maxima before 2010} \\
\hline & & $\begin{array}{l}\text { Level above } \\
\text { «॥», cm }\end{array}$ & Data & $\begin{array}{c}\text { Height of } \\
\text { flood wave, } m\end{array}$ & $\begin{array}{l}\text { Observation } \\
\text { period }\end{array}$ & Level, cm & Data \\
\hline 1 & 2 & 3 & 4 & 5 & 6 & 7 & 8 \\
\hline 1 & Ingolstadt & 485 & 04.06 & - & 1827-2009 & 778 & 18.06.1910 \\
\hline 2 & Regensburg & 497 & 04.06 & 1.8 & 1884-2009 & 666 & 28.03.1988 \\
\hline 3 & Passau & 861 & 03.06 & - & 1877-2009 & 1,230 & 10.07.1954 \\
\hline 4 & $\operatorname{Linz}$ & 497 & 04.06 & - & 1893-2009 & 963 & 11.07.1954 \\
\hline 5 & Kienstock & 821 & 04.06 & - & 1830-2009 & 1,085 & 14.08.2002 \\
\hline 6 & Bratislava & 832 & 05.06 & 5.1 & 1823-2009 & 986 & 16.08.2002 \\
\hline 7 & Nagymaros & 683 & 07.06 & - & 1876-2009 & 713 & 4.04 .2006 \\
\hline 8 & Budapest & 827 & 08.06 & 6.0 & 1876-2009 & 856 & 4.04 .2006 \\
\hline 9 & Mohacs & 923 & 11.06 & 6.4 & 1876-2009 & 984 & 19.06.1965 \\
\hline 10 & Bezdan & 723 & 11.06 & 5.9 & 1876-2009 & 776 & 24.06 .1965 \\
\hline 11 & Bogojevo & 765 & 13.06 & - & 1890-2009 & 817 & 15.06 .1965 \\
\hline 12 & Novi Sad & 694 & $14-15.06$ & 4.6 & 1888-2009 & 778 & 30.06 .1965 \\
\hline 13 & Zemun & 662 & 14.06 & - & 1876-2009 & 783 & 17.04 .2006 \\
\hline 14 & Bazias & 702 & $30.06-01.07$ & 1.0 & 1874-2009 & 807 & $15-17.04 .2006$ \\
\hline 15 & Orsova & 2520 & 19.07 & - & $1971-2009$ & 2,568 & 17.10 .1994 \\
\hline 16 & Turnu Severin & 895 & 02.07 & 1.7 & 1879-2009 & 928 & 27.04 .2006 \\
\hline 17 & Novo Selo & 805 & 01.07 & - & $1941-2009$ & 922 & 20.04 .2006 \\
\hline 18 & Calafat & 710 & 02.07 & 4.8 & 1879-2009 & 861 & $22-23.04 .2006$ \\
\hline 19 & Lom & 869 & 02.07 & - & 1921-2009 & 985 & 23.04 .2006 \\
\hline 20 & Zimnicea & 710 & 04-05.07 & - & 1879-2009 & 839 & 24.04 .2006 \\
\hline 21 & Giurgiu & 727 & 05.07 & 4.6 & 1879-2009 & 822 & 24.04 .2006 \\
\hline 22 & Oltenita & 722 & 10.07 & - & 1879-2009 & 809 & 24.04 .2006 \\
\hline 23 & Hirsova & 746 & 07.07 & 4.1 & 1898-2009 & 764 & 25.04 .2006 \\
\hline 24 & Braila & $713^{*}$ & 06.07 & - & 1874-2009 & 699 & 26.04 .2006 \\
\hline 25 & Reni & $581^{*}$ & 06.07 & 2.8 & $1921-2009$ & 562 & 26.04 .2006 \\
\hline 26 & Izmail & 399 & $06-07.07$ & 1.9 & 1921-2009 & 420 & 22.05.1970 \\
\hline 27 & Kiliya & 241 & 11.07 & 1.1 & 1921-2009 & 282 & 02.04.1942 \\
\hline 28 & Vilkovo & 177 & $10-11.07$ & 0.6 & 1921-2009 & 191 & 19.02.1979 \\
\hline 29 & Primorskoye & 531 & 10.07 & 0.2 & 1951-2009 & 599 & 19.02.1979 \\
\hline
\end{tabular}


During the spring-summer flood in 2010, the maximum water discharge ever seen over the entire period of observations from the year 1840 was recorded in the Ukrainian part of the Danube River. According to the stage-discharge curve (Гидрология дельты Дуная, 2004), the water level at Reni, which exceeded the historical maximum by $19 \mathrm{~cm}$ (the historical maximum was reached during the previous high spring-summer flood in 2006), corresponds to the water discharge of about $17,000 \mathrm{~m}^{3} / \mathrm{s}$. According to rough estimates, the probability of this water discharge is $0.7-0.8 \%$, and its frequency is once in 125-140 years (the probability curve of the maximum water discharges for the period of 1971-2002 was used in calculations (Гидрология дельты Дуная, 2004).

In spite of the extreme water levels and discharges, as well as the inundation, which covered the river floodplain, no considerable damage was caused to the population or the national economy. Following the 2002 flood, protection measures along the Danube were carried out, and the flood warning system was developed.

\section{Conclusions}

Extreme hydrological events in the Danube River basin in the last decades can be considered as consequences of large-scale climate change. These hydrometeorological changes include air and water temperature rise, softening of ice conditions, increase of total precipitation, increase of the Danube River average water discharges, eustatic rise of the Black Sea level, and more frequent high summer and spring-summer floods. In this article, the extreme rainfall flood in August 2002 and spring-summer floods in 2006 and 2010 were discussed.

The main causes of these 3 extreme hydrological events were abnormal rainfalls in most parts of the Danube River basin and, in 2006 and 2010, the large amount of snow accumulated by the beginning of snowmelt in the upper and middle parts of the basin. During a springsummer flood, 2 waves are usually formed: an earlier wave mainly caused by snowmelt and a later wave caused by rains. During the spring-summer flood in 2006, the snowmelt flow predominated, and in 2010, the rainfall flow played the main role. In the former case, the first spring-summer flood wave was more intense, while in the latter case, the second wave was more intense.

The values of historical maxima of water levels during these 3 events under study were exceeded at a total distance of more than $2,000 \mathrm{~km}$ (from gauging station of Kienstock in Austria to the Danube delta head). During the flood in 2002, the water levels exceeded their historical maxima on the upper Danube and partially on the middle Danube; during the flood in 2006, the water levels exceeded historical maxima on the middle and lower Danube, and in 2010 - only on the lower Danube.

It takes the flood wave about a month to move from upper reaches of the river to the sea. The influence of the large tributaries Morava, Tisza, Sava, Siret and Prut is very important. There are 2 zones where flood waves flatten: a reach upstream the Iron Gate I Reservoir and a zone caused mainly by the relatively stable sea level. Along these zones, a rate of flood waves movement decreases. The evaluated probabilities of the floods in 2006 and 2010 based on the old probability curve were about 1 and $0.7-0.8 \%$. It is obvious that the new probability curves are urgently needed for different cross-sections of the Danube River.

The extreme hydrological events in 2002, 2006 and 2010 were accompanied by severe inundations in many areas adjoining the Danube River, particularly, in Austria, Slovakia, Hungary and Romania. Considerable damage affected the population and national economy of these countries.

During the events described above, hydrometeorological agencies in the Danubian countries responsible for observations, information exchange, forecasting and population warning demonstrated their effective work.

\section{Acknowledgements}

I would like to thank Prof. V. N. Mikhailov from the Faculty of Geography, Moscow State University (Moscow, Russia) for his helpful and critical comments on this work. I am very grateful to V. N. Morozov and his colleagues from the Danube Hydrometeorological Observatory (Izmail, Ukraine) for scientific cooperation. 


\section{References}

Dunărea între Baziaş şi Ceatal Izmail. Monografic Hidrologică (The Danube from Baziaş to Ceatal Izmail. Hydrological Monograph) (1967), 369 pp., Bucureşti, Romania.

Flood Action Programme. Action Programme for Sustainable Flood Protection in the Danube River Basin (2004) Available at: https://www.icpdr.org/flowpaper/viewer/default/files/ ICPDR_Flood\%20_Action_Programme.pdf

Flood Risk Management. Available at: http://www.icpdr.org/ main/activities-projects/flood-risk-management

Hydrology of the Danube (1988) 351 pp. Bratislava, Slovakia: Priroda.

IPCC, 2013: Climate Change 2013: The Physical Science Basis. Contribution of Working Group I to the Fifth Assessment Report of the Intergovernmental Panel on Climate Change. Cambridge University Press, Cambridge, United Kingdom and New York, NY, USA, 1535 p.
Mikhailov V.N., Mikhailova M.V., Morozov V.N., Kornilov M.V. and Khudoleev V.N. (2004) Catastrophic Flood on the Danube in August 2002. Russian Meteorology and Hydrology 29(1): 53-58.

Mikhailov V.N., Morozov V.N., Cheroy N.I., Mikhailova M.V. and Zav'yalova Ye.F. (2008) Extreme flood on the Danube River in 2006. Russian Meteorology and Hydrology 33(1): 48-54. https://doi.org/10.3103/S1068373908010081

Mikhailova M.V., Mikhailov V.N. and Morozov V.N. (2012) Extreme hydrological events in the Danube River basin over the last decades. Water Resources 39(2): 161-179. https://doi. org/10.1134/S0097807812010095

Гидрология дельты Дуная (Hydrology of the Danube delta) (2004) 448 pp. Moscow, Russia: GEOS.

\section{Ekstremalūs šiandienos potvyniai ir jų transformacija prie Dunojaus upès}

Gauta: $2017 \mathrm{~m}$. balandis

Priimta spaudai: 2017 m. liepa

\section{Maria Mikhailova}

Vandens problemų institutas, Rusijos mokslų akademija, Maskva, Rusija

Straipsnyje aptariami reikšmingi meteorologinių sąlygų ir hidrologinio režimo pokyčiai Dunojaus upės baseine, vykstantys nuo XX a. pabaigos iki XXI a. pradžios. Ypatingas demesys skiriamas pastariesiems ekstremaliems hidrologiniams jvykiams Dunojaus upės baseine: katastrofiškam lietaus potvyniui, jvykusiam 2002 m. rugpjūčio mèn. ir ypač didžiuliams pavasario-vasaros potvyniams jivykusiems 2006 m. ir 2010 m. Šiame straipsnyje detaliai aptariamos specifinès Dunojaus upės potvynių bangų vystymosi ir transformacijos ypatybès ir jų poveikis Iron Gate I rezervuarui. Be to, darbe jivertintas Juodosios jūros užtvankos poveikis bei apytiksliai jvertinta ekstremalių galimų potvynių tikimybès.

Raktiniai žodžiai: Dunojus, lietus, sniego tirpimas, ekstremalus potvynis. 